Leuven Centre for Global Governance Studies

Working Paper No. 29 - June 2009

In Search of a Balanced Relationship: Public And Private FOOD SAFETY STANDARDS AND INTERNATIONAL LAW

\author{
Jan Wouters \\ Axel Marx \\ Nicolas Hachez
}

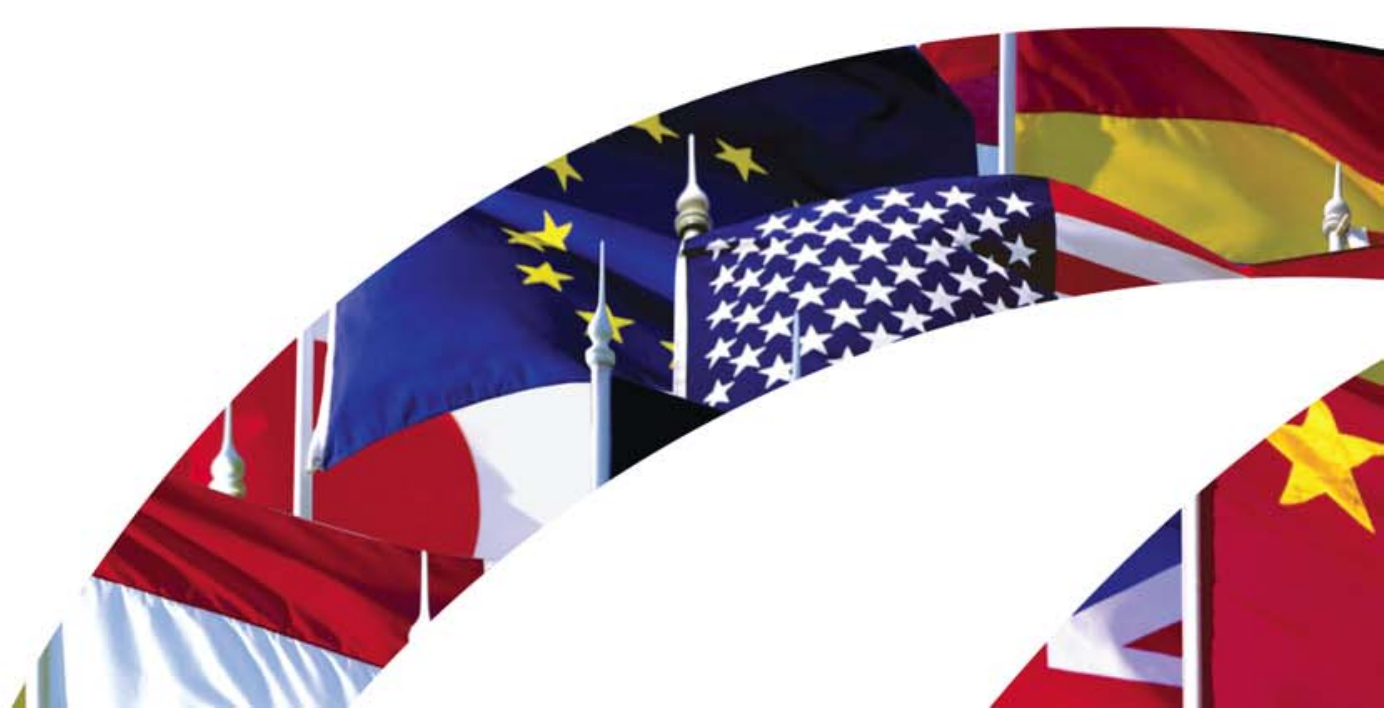




\title{
In Search of a Balanced Relationship: Public and Private Food SAFETY STANDARDS AND INTERNATIONAL LAW
}

\author{
Jan Wouters \\ Axel Marx \\ Nicolas Hachez
}

\begin{abstract}
The purpose of this paper is thus to analyze how the interconnection between international food safety standards and the rules of free trade is playing out and what the end-result of such interplay is for the potentially conflicting objectives of free trade and food safety. In performing this analysis, the paper opposes the merits of two types of food safety standards, public and private standards, in order to determine which of them is more likely to constitute an appropriate regulatory model for transnational food safety in the context of the WTO-led liberalization of the international trade in food products. The paper opposes two concrete examples of such standards, namely the public Codex Alimentarius standards, which have been assigned a formal role by the WTO; and the private GLOBALG.A.P. Standard for agricultural products, which is developed in isolation from international trade rules.
\end{abstract}

\section{KEY WORDS}

Global Food Governance, Food Safety, Private Standards, World Trade Organization, Codex Alimentarius, International Law

\section{AUTHORS}

Jan Wouters, Professor of International Law and International Organizations, Director of the Leuven Centre for Global Governance Studies and the Institute for International Law, University of Leuven

Axel Marx, Research Coordinator of the Leuven Centre for Global Governance Studies, University Leuven

Nicolas Hachez, Junior Member of the Leuven Centre for Global Governance Studies, Researcher at the Institute for International Law, University Leuven

\section{ADDRESS FOR CORRESPONDENCE}

jan.wouters@ggs.kuleuven.be axel.marx@ggs.kuleuven.be

nicholas.hachez@law.kuleuven.be 


\section{CONTENTS}

1. INTRODUCTION 3

2. THE LIBERALIZATION AgENDA AND MARKET ACCESS 5

2.1. STANDARDS AND THE WTO: THE AGREEMENTS 6

2.2. TBT AGREEMENT 6

2.3. SPS AGREEMENT 8

3. THE HARMONIZATION STRATEGY IN FOOD SAFETY STANDARDS AND ITS 9

CHALLENGE UNDER THE WTO

3.1. LINKAGE BETWEEN SPS AgREEMENT AND CODEX ALIMENTARIUS COMMISSION 10

STANDARDS

3.2. QUESTIONS OF EFFECTIVENESS AND LEGITIMACY 12

3.2.1. Dynamism and Efficiency 12

3.2.2. Institutional Design 13

3.2.3. Public Interest Oriented Character 15

3.3. LINKAGE BETWEEN SPS AGREEMENT AND SPS STANDARDS IS TOO TIGHT AND 17 RUNS COUNTER TO FOOD SAFETY OBJECTIVES

4. Alternatives to Public Standardization of Food Products by the 19 CODEX: THE CASE FOR OR AGAINST PRIVATE STANDARDS

4.1. THE DEBATE ABOUt PRIVATE StandaRdS AND FREE TRADE AT THE WTO 20

4.2. PRIVATE StANDARDS AND REgULATION OF FOOd PRODUCTS 21

$\begin{array}{ll}\text { 4.2.1. Presentation of GLOBALG.A.P. } & 21\end{array}$

4.2.2. Assessment of GLOBALG.A.P. from an Effectiveness and 24

Legitimacy Perspective

4.2.3. GLOBALG.A.P. and the Trade Issue 26

5. CONCLUSION 


\section{INTRODUCTION}

As a result of numerous food crises that have scared the world in the past decades e.g. the mad cow disease, the foot and mouth disease, the dioxin in chicken meat, etc. - the safety of food products has become a major concern to consumers, producers, suppliers and public authorities worldwide. On the other hand, food products are among the most widely traded goods across the planet. These conditions pose a dilemma.

On the one hand, the general public wants to be sure that the food they purchase in their local supermarket is safe for consumption. Thus, they demand for high standards of food safety to be set for products that are allowed to be sold in domestic markets. Therefore, domestic and international public authorities have taken numerous legal measures to ensure the level of safety demanded by consumers. At the same time, private actors such as supermarket chains and large food producers have also set their own standards of food safety, which very often go beyond the exigencies of national or international legislations. As a result of the globalization of food markets, such private standards are often set on a transnational basis by multinational actors. There are several reasons why the private sector seeks to set its own standards for food safety: producers and supermarket chains want to reassure consumers by setting extra-high safety standards; they want to establish a competitive advantage for their products based on their level of safety; or they want to be able to demonstrate that extra care was taken in relation to food safety in case their (legal) responsibility is engaged as a result of a food crisis. Given such dynamics, we encounter a myriad of differing public and private food standards that potentially apply to a vast amount of food products being sold in food stores across the world. And it is this very phenomenon that the following paper intends to analyze. In doing so, we shall focus our analysis on a fundamental distinction regarding food standards, that is, between public standards (adopted by a public authority, either as a legal requirement, or as guidance), and private standards (adopted by a private actor).

On the other hand, this dilemma, as it concerns food products is only further complicated. Food products are extensively traded internationally and are thus intended to circulate widely between national markets. Such food circulation represents high stakes for the international trade system, which is regulated at the international level by the World Trade Organization. The ultimate objective of the WTO is to liberalize trade and lift barriers which could hinder the free circulation and trade of products and services across the globe. In this respect, the multiplication of food standards adopted by public authorities and private actors is potentially problematic: in order to enter differing national markets, food products may have to comply with various food safety requirements, which potentially creates great difficulties for the free trading of such goods. This is why the WTO has adopted a strategy to help liberalizing the trade in food products in relation to the issue of food safety, namely to harmonize food standards across the globe, so that all food products would have to comply with as few standards as possible in order to be able to access every local market in the world. This strategy has been legally embodied in the Agreement on Sanitary and Phytosanitary Measures (the SPS Agreement), which will be presented infra.

The purpose of this paper is thus to analyze how the interconnection between international food safety standards and the rules of free trade is playing out and what the end-result of such interplay is for the potentially conflicting objectives of free trade and food safety. In performing this analysis, we shall oppose the merits of two types of food safety standards, public and private as defined above, in order to determine which of them is more likely to constitute an appropriate regulatory model 
for transnational food safety in the context of the WTO-led liberalization of the international trade in food products. We shall more precisely oppose two concrete examples of such standards, namely the public Codex Alimentarius standards, which, as we shall see, have been assigned a formal role by the WTO; and the private GLOBALG.A.P. Standard for agricultural products, which is developed in isolation from international trade rules.

In confronting the appropriateness of these public and private standards, we shall make use of a twofold benchmark that will aid us in evaluating the effectiveness and the legitimacy of public and private standards in order to determine what the best regulatory model would be. ${ }^{1}$

We understand the effectiveness of food standards as the ability to internationally impose a desirable level of food safety while not exaggeratedly hindering the free trade in food products. Our analysis in this regard shall draw from the line of reflexive law scholarship as applied to transnational governance. ${ }^{2}$ According to this view, in a transnational regulatory context characterized by networks of actors and interests interacting globally, which is not organized according to predefined hierarchical relationships, central national administrations can no longer efficiently assume the whole of regulatory functions, even in close coordination with each other. Regulation is deemed to be most effective when it takes advantage of the flows of influence running through those networks of actors. Therefore, rather than adopt a traditional command-and-control model, we argue that transnational food safety regulation should strive to channel the regulatory initiatives of the existing dynamic networks of actors in the food trading industry (public actors, consumers, producers, retailers, etc.) in order to reach socially desirable levels of food safety and free trade. According to this approach, the role of the "law" and of the "administration" is to position itself as a facilitator for the adoption of appropriate standards by the actors interested in food safety and free trade, notably, in the case of food products, by influencing market mechanisms or consumptions patterns. This approach is however not confined to "governing through markets", but sometimes implies to establish real regulatory institutions to tackle a particular issue, such as specialized standardsetting organizations. ${ }^{3}$ This approach has different advantages, notably that regulation will potentially benefit from the expertise of a very large pool of regulators/regulatees and that it will be very dynamic and sensitive to changes in needs concerning food safety and free trade.

\footnotetext{
${ }^{1}$ In this regard, we intend to inspire ourselves from the analysis F. Ost \& M. van de Kerchove base the "validity" of legal norms on three interrelated criteria: formal validity, effectiveness and legitimacy. We shall attempt to transpose their analysis of legal orders to the looser and broader transnational regulatory context. In this perspective, the "validity" of a regulatory norm must understood as the recognition, in a certain regulatory regime, that such or such norm (or, in this case, food product standard) is may have the regulatory effects that its authors intended to give it. See F. OST \& M. VAN DE KERCHOVE, De la Pyramide au Réseau - Pour une Théorie Dialectique du Droit, Brussels, Publications des Facultés Unviersitaires Saint-Louis, 2002, pp. $307 \mathrm{ff}$. We shall, in the context of this paper, leave the question of the formal validity of food standars aside, as it does not fit well in the context of the little institutionalized and weakly formalized transnational regulatory context. However, to compensate the relative inoperability of the formal validity criteria, we shall attach increased importance to the two other criteria of effectiveness and legitimacy, which are concepts that have extensively been discussed in the debate about the forms of transnational regulatory governance.

${ }^{2}$ See G. TEUBNER, "Substantive and Reflexive Elements in Modern Law", 17 Law \& Society Review 239, 1983.

${ }^{3}$ See notably A. C. AMAN, "The Limits of Globalization and the Future of Administrative Law: From Government to Governance”, 8 Ind. J. Global Legal Stud. 379, 2000-2001; R. STEWART, "Administrative Law in the Twenty-First Century", 78 N.Y.U. L. Rev. 437, 2003; O. LOBEL, "The Renew Deal: the Fall of Regulation and the Rise of Governance in Contemporary Legal Thought”, 89 Minn. L. Rev. 342, 2004.
} 
The legitimacy side of the analysis will be based on the principle of democracy in decision-making. Many students of global governance have discarded democracy as invalid for analyzing transnational regulation, notably in view of the fact that there was no transnational political community to which the concept of democracy as a legitimizing principle could be applied. Such students have therefore tended to replace the concept of democracy by a more or less variable list of other characters which could be, for want of a unified theory, used in assessing the legitimacy of global governance institutions and regulations. ${ }^{4}$ On the contrary we believe that wherever public regulation is taking place, the ultimate legitimizing principle of such regulation should be its democratic character. Even though we are fully aware that constitutional democracy as it is practiced in domestic legal orders is not transposable as such to transnational regulatory regimes such as food safety standard setting and international trade, the concept of democracy itself is in fact a complex of principles - that of equality, broad and open participation, transparency, accountability and the search for the public interest - all of which can successfully be put to use when assessing the legitimacy of transnational regulatory schemes. ${ }^{5}$ Our analysis of the legitimacy of public and private international food safety standards will therefore attempt to unravel the operation of the democratic principle in establishing food safety standards. In doing so, emphasis will be put on questions relating to the processes according to which regulatory decisions are made, and the way in which the decision-making institution or forum is designed, as we believe these aspects are instrumental in forming democratic regulation.

\section{The LiBERALizATION AgendA AND MARKET ACCESS}

The international trade regime, embodied in the World Trade Organization, is geared toward the liberalization of international trade, which is supposed to contribute to:

"raising standards of living, ensuring full employment and a large and steadily growing volume of real income and effective demand, and expanding the production of and trade in goods and services, while allowing for the optimal use of the world's resources in accordance with the objective of sustainable development, seeking both to protect and preserve the environment and to enhance the means for doing so in a manner consistent with their respective needs and concerns at different levels of economic development."

A pivotal objective of the trade liberalization agenda is naturally the elimination of all barriers that can and do exist that inhibit the circulation of goods and services among countries. ${ }^{7}$ An important principle in this respect is market access. ${ }^{8}$ By this connection, the international trade regime was first and foremost concerned with

\footnotetext{
${ }^{4}$ See A. BUCHANAN \& R. KEOHANE, “The Legitimacy of Global Governance Institutions”, 20 Ethics \& International Affairs 405, 2006, p. 417; S. BERNSTEIN, "Do Intergovernmental and Nonstate Governance Institutions Rest on Different Bases of Legitimacy?”, June 1, 2008, available at http://www.allacademic.com/meta/p254253_index.html.

${ }^{5}$ See generally G. DE BÚRCA, “Developing Democracy beyond the State”, 46 Colum. J. Transnat'l L. 221, 2008, who advocates a "building block approach" to democracy in transnational contexts, and insists that open and equal participation in decision-making processes is the central feature of democracy.

${ }^{6}$ Agreement Establishing the World Trade Organization, done in Marrakesh on April 15, 1994, preamble.

See generally A. F. LOWENFELD, International Economic Law, International Economic Law Series, Oxford \& New York, Oxford University Press, 2002, pp. 28 ff.

${ }^{8}$ J. WOUTERS \& B. DE MEESTER, The World Trade Organization - A Legal and Institutional Analysis, Antwerp \& Oxford, Intersentia, 2007, pp. 22-23.
} 
quotas and tariffs, that is, customs duties levied on foreign goods to enter a national market. $^{9}$

\subsection{STANDARDS AND THE WTO: THE AGREEMENTS}

Next to quotas and tariffs, diverging standards between countries or industry groups are also likely to create serious restrictions to market access and hamper international commerce. As quotas have virtually disappeared, and as tariffs are under control and generally diminishing, the WTO members have grown increasingly concerned with regulatory barriers to trade, such as food safety standards, which can result from national policies that amount to disguised protectionism. WTO Members have thus also adopted instruments that are more specifically directed at standards, namely the Technical Barriers to Trade Agreement (hereinafter the "TBT Agreement") and the Agreement on Sanitary and Phytosanitary Measures (hereinafter the "SPS Agreement"). As we shall see, harmonization of diverging standards stands at the centre of the barriers-reducing agenda.

\subsection{TBT AGREEMENT}

The TBT Agreement, as its name indicates, envisages standards in their tradedistorting dimension, even if it acknowledges in its preamble "the important contribution that international standards [...] can make in [...] regard [of free trade] by improving efficiency of production and facilitating the conduct of international trade." The TBT Agreement focuses on product standards, and makes a distinction between "standards" as non-legally mandatory instruments, and "technical regulations" as instruments with which compliance is mandatory. ${ }^{10}$ The TBT Agreement is applicable to standards and technical regulations relating to "[a]ll products, including industrial and agricultural products" (Art. 1.3.).

The substantive provisions of the TBT Agreement start by repeating the nondiscrimination principles that are a leitmotiv in WTO texts (known in the international trade terminology as the principles of "national treatment" and "most favored nation"): technical regulations may not discriminate between products originating from different countries, or between foreign and domestic products (Art. 2.1.). In order to mitigate the distorting effects on trade caused by divergent technical regulations regarding products, the TBT Agreement further provides, as fundamental obligations,

\footnotetext{
${ }^{9}$ Article XI 1. of the General Agreement on Tariffs and Trade (GATT) therefore provides that, subject to exceptions, "[n]o prohibitions or restrictions other than duties, taxes or other charges, whether made effective through quotas, import or export licences or other measures, shall be instituted or maintained by any contracting party on the importation of any product of the territory of any other contracting party or on the exportation or sale for export of any product destined for the territory of any other contracting party."

${ }^{10}$ The definitions of both concepts are however very close, and are inspired by the ISO/IEC Guide No. 2 on Standardization and Related Activities - General Vocabulary. Let us note that the definitions do not encompass de facto standards, but only those standards that are designed as a result of a formal rule-making process.

The definition of Technical regulation reads as follows: "Document which lays down product characteristics or their related processes and production methods, including the applicable administrative provisions, with which compliance is mandatory. It may also include or deal exclusively with terminology, symbols, packaging, marking or labelling requirements as they apply to a product, process or production method.” (TBT Agreement, Annex 1, Art. 1.)

The definition of Standard reads as follows: "Document approved by a recognized body, that provides, for common and repeated use, rules, guidelines or characteristics for products or related processes and production methods, with which compliance is not mandatory. It may also include or deal exclusively with terminology, symbols, packaging, marking or labelling requirements as they apply to a product, process or production method.” (TBT Agreement, Annex 1, Art. 2.)
} 
that technical regulations should not be prepared, adopted or applied with the intent or the effect of creating unnecessary obstacles to trade, and that technical regulations shall not be more trade-restrictive than necessary to fulfill legitimate objectives, among which the TBT Agreement lists, for example, national security requirements; the prevention of deceptive practices; the protection of human health or safety, animal or plant life or health, or the environment (Art. 2.2.). Implementing the WTO strategy of harmonization of national policies, Article 2.4. requires Member states to base their technical regulations on relevant "international standards" (without further precision or definition) where they exist, except when that would be ineffective or inappropriate for the fulfillment of the legitimate objective (Art. 2.4.). In order to enhance the speed of harmonization, Member states are also expected to participate in the development of international standards (Art. 2.6.), and to "give positive consideration" to giving mutual recognition to technical regulations of other members provided they are fit for fulfilling the legitimate purpose (Art. 2.7.). Member states further undertake to take reasonable measures to ensure that local government bodies and non-governmental bodies will comply with the above in their standardization activities (Art. 3.1.).

Annex 3 of the TBT Agreement consists of a "Code of Good Practice for the Preparation, Adoption and Application of Standards", which is addressed to and open to voluntary acceptance by all standardizing bodies, whether regional, central government, local government or non-governmental (Annex 3, Point B.). The Code reiterates the principles of non-discrimination and of minimal effect on trade. ${ }^{11}$ Pursuant to the harmonization agenda, standardizing bodies are also urged to use international standards in the definition of their own standards and to participate in the preparation thereof (Annex 3 , points $F \& G$ ). Interesting in this regard is the strategic partnership that the WTO seems to have concluded with the private International Organization for Standardization ("ISO") to manage the "internationalization" of standardization activities. Addressees of the code are indeed required to notify their adhesion or withdrawal to the ISO Information Center in Geneva (Annex 3, Point C.). Also standardizing bodies are requested to "associate themselves" with the national member of ISONET, which is the ISO Information Network. ${ }^{12}$

The Code then provides short guidelines as to procedural practices that should govern the preparation and adoption of standards, and notably advocates providing notice-and-comment opportunities to "interested parties".

Article 4.1. of the TBT Agreement provides that Member states must ensure that their central standardizing body complies with the Code of Good Practice, and that they must take reasonable measures so as to ensure that standardizing bodies which do not directly depend from the government also accept and comply with the Code of Good Practice.

\footnotetext{
11 Art. 4.2. of the TBT Agreement provides that “ [s]tandardizing bodies that have accepted and are complying with the Code of Good Practice shall be acknowledged by the Members as complying with the principles of this Agreement.”

${ }^{12}$ More precisely, "ISONET is an agreement between standardizing bodies to combine their efforts to make information on standards, technical regulations and related matters readily available. ISONET is founded on the principle that in each country there is a body - usually the ISO member - which has a broad knowledge of standardizing and regulatory activities in that country. As a party to ISONET, the body in question agrees to expand this knowledge to the utmost extent and to share its experience and exchange information as required with similar bodies in other countries." See INTERNATIONAL ORGANIZATION FOR STANDARDIZATION, ISONET - ISO Information Network, 2001, available at http://www.iso.org/iso/prods-services/otherpubs/pdf/informationisonet.pdf, p. 2.
} 
Finally, disputes between Member states involving the TBT Agreement are submitted to the Dispute Settlement Understanding. (Art. 14)

\subsection{SPS AGREEMENT}

The Agreement on Sanitary and Phytosanitary Measures derogates from the TBT Agreement and applies to all Sanitary and Phytosanitary Measures as a particular type of technical barrier to trade. ${ }^{13}$ The SPS Agreement expressly relates to Article XX(b) of the GATT, which provides for "general exceptions" to the GATT discipline for measures that are "necessary to protect human, animal or plant life or health." According to the SPS Agreement, Member states are thus allowed to take such measures, but only "to the extent" necessary. Moreover, those measures must be "based on scientific principles and not be maintained without sufficient scientific evidence" (Art. 2.1.).

The main objective of the SPS Agreement is to harmonize diverging SPS measures throughout the world, so as to eliminate the trade barriers they create. In order to achieve harmonization, Member states are required to base their SPS measures on "international standards". Measures based on such international standards are then deemed to comply with the SPS Agreement (Art. 3.1. and 3.2.). The "international standards" that are recognized as particularly relevant and definitely probative of compliance with the SPS Agreement are those developed by the Codex Alimentarius Commission (hereinafter the "Codex"), the International Office of Epizootics, and the international and regional organizations operating within the framework of the International Plant Protection Convention (Art. 3.4.). The SPS Agreement therefore expressly links the work of those organizations to the harmonization enterprise and to the trade liberalization agenda. We will analyze below the effect that this linkage has on the work of the Codex, on the adoption of food standards and more generally on the overall promotion of food safety. Member states are allowed to set standards that are higher than the relevant international standards, but must then be able to provide a scientific justification for such deviation, or demonstrate that it is necessary following a risk assessment based on scientific principles (Art. 3.3.).

In any event, all SPS measures must be based on an assessment of the risk posed by the food product in question, and such risk assessment must be based on available scientific evidence and take into account the general objective of trade facilitation (Art. 5). The requirement of scientific justification is somewhat mitigated by

${ }^{13}$ Sanitary and Phytosanitary Measures are defined in Annex 1 to the SPS Agreement as: " Any measure applied:

(a) to protect animal or plant life or health within the territory of the Member from risks arising from the entry, establishment or spread of pests, diseases, disease-carrying organisms or disease-causing organisms;

(b) to protect human or animal life or health within the territory of the Member from risks arising from additives, contaminants, toxins or disease-causing organisms in foods, beverages or feedstuffs;

(c) to protect human life or health within the territory of the Member from risks arising from diseases carried by animals, plants or products thereof, or from the entry, establishment or spread of pests; or

(d) to prevent or limit other damage within the territory of the Member from the entry, establishment or spread of pests.

Sanitary or phytosanitary measures include all relevant laws, decrees, regulations, requirements and procedures including, inter alia, end product criteria; processes and production methods; testing, inspection, certification and approval procedures; quarantine treatments including relevant requirements associated with the transport of animals or plants, or with the materials necessary for their survival during transport; provisions on relevant statistical methods, sampling procedures and methods of risk assessment; and packaging and labelling requirements directly related to food safety.” 
Article 5.7., a safeguard clause that the WTO Appellate Body has identified as an expression of the precautionary principle ${ }^{14}$ :

"[i]n cases where relevant scientific evidence is insufficient, a Member may provisionally adopt sanitary or phytosanitary measures on the basis of available pertinent information, including that from the relevant international organizations as well as from sanitary or phytosanitary measures applied by other Members. In such circumstances, Members shall seek to obtain the additional information necessary for a more objective assessment of risk and review the sanitary or phytosanitary measure accordingly within a reasonable period of time."

Private standards regarding food safety fall arguably within the scope of the SPS Agreement, and Article 13 requires Member states to take "reasonable measures" to ensure that non-governmental entities comply with the Agreement. Like the TBT Agreement, disputes between states involving the SPS Agreement are subject to the WTO's Dispute Settlement Understanding (Art. 11).

In conclusion, the SPS Agreement is a trade agreement: it is aimed at reducing as much as possible the barrier effect of SPS measures by WTO Member states. The main tool for achieving this goal is to require the use of scientific evidence to design SPS measures. The obligation to scientifically justify their SPS measures would deter states from adopting SPS measures that are in reality disguised protectionist measures. The harmonization objective is also enhanced by the presumption of compliance that is attached to SPS measures complying with standards developed by three outside international organizations. In our analysis of food safety standardization in the context of the international trade regime, we shall focus on the relations between the SPS Agreement and the Codex standards, as the latter are more specifically applicable to food products.

\section{THE HaRmonization StRategy in FoOd SAFETy Standards and ITS CHALLENGES UNDER THE WTO}

The problem for free trade is not food safety regulations and standards themselves. The preamble of the SPS Agreement explicitly recognizes that "no Member should be prevented from adopting or enforcing measures necessary to protect human, animal or plant life or health". The fact that governments should protect their citizens from unsafe or unhealthy food products and are allowed to set forth health and safety requirements on the products that enter their markets is not in discussion. ${ }^{15}$ What is problematic, however, is the fact that such regulations and standards diverge among countries and industry sectors, and that the products complying with the regulations in force in one country or industry sector will not necessarily comply with those of another country or industry sector and will therefore be prevented from entering the market. Therefore, the aim of the SPS Agreement is "to define a set of standards or regulations which will be minimally trade distorting but which will yet achieve different countries' social objectives about the extent to which their citizens are exposed to unsafe or low-quality foods." ${ }^{16}$

\footnotetext{
${ }^{14}$ Appellate Body Report, EC Measures Concerning Meat and Meat Products (Hormones) - AB-19974, January 16, 1998, Doc. Nos. WT/DS26/AB/R \& WT/DS48/AB/R, §§ 123-124.

${ }^{15}$ According to A. F. LOWENFELD, op. cit., p. 324, “[t]he SPS Agreement essentially seeks to spell out in a limited area the principle of Article XX(b) of the GATT."

16 D. MACLAREN, “Trade Barriers and Food-Safety Standards", available at http://rspas.anu.edu.au/economics/publish/papers/aciar/aciar_2002_mclaren.pdf, 2002, p. 2.
} 
As the WTO mandate is limited to international trade issues, it has no legislative capacity to positively harmonize food standards through international instruments of its own. The WTO must therefore base its harmonization strategy on substantive international instruments that are developed outside of its ambit. In doing so, two strategies open up: integration of international standards developed by other international bodies, and mutual recognition of national standards. ${ }^{17}$ WTO instruments use both mechanisms ${ }^{18}$, but given the scope of this article, we shall focus our analysis on the integration strategy, which the WTO has adopted by linking the standards defined by the Codex to compliance with the SPS Agreement.

Next to the reasons pertaining to the lack of a legislative mandate in the food safety sector, one could also argue that the WTO has taken the stance of harmonizing through integration because it is mindful to leave the substantive work of setting food standards, which can be quite technical, to specialized institutions. ${ }^{19}$ Such strategy is however raising many concerns, notably that such large scale harmonization of health issues will lead to a worldwide "ratcheting down" in the protection of health, or that the designated bodies are vulnerable to capture and hence unlikely to be working in the general interest. ${ }^{20}$ In the next subsections, we shall analyze the merits of such criticisms with regard to the relations between the Codex and the SPS Agreement.

\subsection{LinKAge BetWeen SPS AgREement AND CodeX Alimentarius Commission STANDARDS}

The Codex Alimentarius Commission was created in 1961 and 1963 by two resolutions of the Food and Agriculture Organization of the United Nations ("FAO") and of the World Health Organization ("WHO") with the purpose of making recommendations to and being consulted by the relevant organs of the FAO and the WHO:

"on all matters pertaining to the implementation of the Joint FAO/WHO Food Standards Programme, the purpose of which is:

(a) Protecting the health of the consumers and ensuring fair practices in the food trade;

(b) Promoting coordination of all food standards work undertaken by international governmental and non governmental organizations;

(c) Determining priorities and initiating and guiding the preparation of draft standards through and with the aid of appropriate organizations;

(d) Finalizing standards elaborated under (c) above and publishing them in a Codex Alimentarius either as regional or worldwide standards, together with international standards already finalized by other bodies under (b) above, wherever this is practicable;

(e) Amending published standards, as appropriate, in the light of developments." 21

\footnotetext{
${ }^{17}$ G. MARCEAU \& J. P. TRACHTMAN, “The Technical Barriers to Trade Agreement, the Sanitary and Phytosanitary Measures Agreement, and the General Agreement on Tariffs and Trade - A Map of the World Trade Organization Law of Domestic Regulation of Goods”, 36:5 Journal of World Trade 811, 2002, pp. 837-838.

${ }^{18}$ See TBT Agreement, art. 2.7.; and SPS Agreement, art. 4.

${ }^{19}$ See WORLD TRADE ORGANIZATION, Exploring the Links between Trade, Standards and the WTO, World Trade Report, 2005, available at http://www.wto.org/english/res_e/booksp_e/anrep_e/world_trade_report05_e.pdf (hereinafter “World Trade Report 2005”), pp. 160-161.

${ }^{20}$ J. SCOTT, "International Trade and Environmental Governance: Relating Rules (and Standards) in the EU and the WTO”, 15 Eur. J. Int'l L. 307, 2004, p. 324.

${ }^{21}$ Statutes of the Codex Alimentarius Commission, Article 1.
} 
Membership to the Codex Alimentarius Commission is open to all members and associate members of FAO and WHO which are interested in international food standards. Members are states, while associate members are "[t]erritories or groups of territories which are not responsible for the conduct of their international relations." 22

The Codex Alimentarius Commission is presided by a Chairperson and three ViceChairpersons, elected by the Members of the Commission among the delegates of the Members. Those officers may preside the meetings of the Commission and "exercise such other function as may be required to facilitate the work of the Commission." The officers also form part of the "Executive Committee", elected by Members on a geographic basis, which is the executive organ of the Commission. Its primary functions are to "make proposals to the Commission regarding the general orientation and programme or work of the Commission, study special problems and help implement the programme as approved by the Commission." ${ }^{23}$

The Commission may establish "Subsidiary Bodies", notably in the form of "Codex Committees for the preparation of draft standards for submission to the Commission, whether intended for world-wide use, for a given region or for a group of countries specifically enumerated by the Commission.." ${ }^{24}$ Such Committees shall be composed of scientific experts in the relevant field, who are representatives of Members having expressed the desire to take part in the Committee, or of Members designated by the Committee. Moreover, the Commission may grant observer status to particularly interested non-members, international or non-governmental organizations. ${ }^{25}$

The Commission is also assisted by a Secretariat, based at the seat of the FAO in Rome, and appointed by the Directors-General of the FAO and the WHO. It further functions in arranging for the preparation of the "proposed draft standard" when the Commission has decided that such a standard should be developed. ${ }^{26}$

Decisions of the Commission and of the Subsidiary Bodies are normally taken at the absolute majority, each Member having one vote. ${ }^{27}$ However, "[t]he Commission [and the Subsidiary Bodies] shall make every effort to reach agreement on the adoption or amendment of standards by consensus. Decisions to adopt or amend standards may be taken by voting only if such efforts to reach consensus have failed." 28

The Commission may adopt three types of food-related standard documents, all of which are formally voluntary: the "Codex Standards", which relate to one or several product characteristics; the "Codex Codes of Practice", which relate to the production, processing, manufacturing, transport and storage practices for individual

\footnotetext{
${ }^{22}$ FAO Constitution, Article II; WHO Constitution, Article 6.

${ }^{23}$ CODEX ALIMENTARIUS COMMISSION, Procedural Manual (17 $7^{\text {th }}$ ed.), "Rules of Procedure of the Codex Alimentarius Commission", available at ftp://ftp.fao.org/docrep/fao/005/Y2200E/Y2200E00.pdf, Rule III, 2. (Hereinafter "Rules of Procedure")

${ }^{24}$ Id., Rule IX, 1(b) (i). Such Committees notably consist of "General Subject Committees", whose work is relevant to all commodity standards (ex.: the Committee on Food Additives); and of "Commodity Committees", whose work is related to specific foods or food groups (ex.: the Committee on Fresh Fruits and Vegetables).

${ }^{25}$ Id., Rule VII.

${ }^{26}$ CODEX ALIMENTARIUS COMMISSION, Procedural Manual (1 $7^{\text {th }}$ ed.), "Procedures for the Elaboration of Codex Standards and Related Texts", available at ftp://ftp.fao.org/docrep/fao/005/Y2200E/Y2200E00.pdf, introduction, 1.

${ }^{27}$ Rules of Procedure, Rule VI.

${ }^{28}$ Id., Rule X, 2.
} 
foods or groups of foods; and the "Codex Guidelines", which either set out policy in key areas or which are intended for interpretative purposes (hereinafter together "Codex Standards"). ${ }^{29}$

The Codex standard documents are prepared according to a complex eight-step decision-making process designed as follows:

"[b]efore a decision is made to undertake the development of a new standard or other text, a project proposal is prepared and discussed at Committee level.

\section{Step 1}

The project proposal is reviewed by the Executive Committee and compared against the criteria and priorities established by the Commission.

\section{Steps 2, 3 and 4}

A draft text is prepared (Step 2) and circulated to member countries and all interested parties for comment (Step 3). The draft and the comments are reviewed at Committee level (Step 4) and, if necessary, a new draft is prepared.

\section{Step 5}

The Commission reviews the progress made and agrees that the draft should go to finalization. After this stage, the draft is also endorsed by the relevant General Subject Committees so that it is consistent with Codex general standards.

\section{Steps 6 and 7}

The approved draft is sent again to governments and interested parties for comment and finalized by the relevant Committee. The draft is submitted to the Commission for adoption.

\section{Step 8}

Following a final round of comments, the Commission adopts the draft as a formal Codex text. The standard, guideline or other text is then published by the Codex Secretariat." ${ }^{30}$

\subsection{QUESTIONS OF EFFECTIVENESS AND LEGITIMACY}

Students of the WTO are generally quite critical of the linkage between trade and food regulation issues as it is achieved in the SPS Agreement. Their criticism usually revolves around such concerns as: dynamism and efficiency; institutional design; and public interest orientedness.

\subsubsection{Dynamism and efficiency}

As to the first concern, one may argue that, by designating once and for all a competent body for setting what it considers to be valid international standards under the SPS Agreement, the WTO runs the risk of stalling the dynamic process which

\footnotetext{
29 See CODEX ALIMENTARIUS COMMISSION, Secretariat, Understanding the Codex Alimentarius, $\quad 3^{\text {rd }} \quad$ ed., $\quad$ Rome, $\quad 2006, \quad$ available ftp://ftp.fao.org/codex/Publications/understanding/Understanding_EN.pdf, pp. 10-11.

${ }^{30}$ CODEX ALIMENTARIUS COMMISSION, Secretariat, Understanding the Codex Alimentarius, op. cit., p. 17.
} 
induces different standard-setting actors to review each other and constantly develop more effective standards out of a competitive spirit. ${ }^{31}$

However, despite such an abstract concern, what is in fact happening on the ground level regarding the Codex standards is quite contrary to the concerns expressed. Analysts note that the private activity in terms of food standards is more vibrant than ever and that a number of private food standards are increasingly imposing themselves as the "drivers of agri-food systems", including in developing countries. ${ }^{32}$ As to the development of those private schemes developed in parallel with Codex standards, Spencer Henson notes that:

"the evolution of private food safety and quality standards is challenging the role of the World Trade Organization (WTO), in particular the Agreement on Sanitary and Phytosanitary Measures (SPS Agreement) and the Agreement on Technical Barriers to Trade (TBT Agreement) and the utility of food standards diplomacy based on government-to-government relations." 33

Therefore, in designating the Codex as its reference in standardization, the WTO did not succeed in outplaying competing private regulatory schemes, but has rather tended to threaten its own relevance in the food safety standards circus. Moreover, the objective of reducing market access distortions through harmonizing standards may also be in jeopardy, as those private schemes are "becoming a primary determinant of market access." ${ }^{34}$ One can therefore conclude that coupling Codex standards with the harmonization agenda has failed to harness the dynamics of the private sector in developing food standards, as private standards keep blossoming in an uncoordinated way, regardless of the trade liberalization objective.

\subsubsection{Institutional Design}

As previously emphasized, an institutional design that is specifically prone to stimulate broad participation from all relevant actors in regulation is an important guarantee of its legitimacy. The different views of those that can be affected by a regulatory process must indeed be allowed to express themselves in a way that will render such process "democratic" and therefore negate the potential "democratic deficit" that exists when private actors are associated to regulatory exercises. In this sense, there is sufficient reason to regard the way the Codex institution is designed and the procedures it follows are rather unsatisfactory.

As an international institution that depends on the FAO and the WHO, full membership to the Codex is reserved to states that are also members of those two organizations. ${ }^{35}$ In this seemingly egalitarian configuration, developing countries actually face many difficulties in participating within the Codex's activities, which entail participating in highly specialized scientific discussions, as well as the maintenance, in Rome, of a permanent team of scientists ${ }^{36}$, which developing

\footnotetext{
${ }^{31}$ See J. F. HANDLER, Down from Bureaucracy: The Ambiguity of Privatization and Empowerment, Princeton, Princeton University Press, 1996, p. 168, as cited O. LOBEL, op. cit., p. 462; and S. HENSON, “The Role of Public and Private Standards in Regulating International Food Markets”, May 2006, available at http://www.ilr1.uni-bonn.de/iatrc/iatrc_program/Session\%204/Henson.pdf, p. 17.

${ }^{32}$ S. HENSON, op. cit., pp. 3-4.

${ }^{33} I d$.

${ }^{34} I d$.

${ }^{35}$ Rules of Procedure, Rule I.

${ }^{36}$ See Rules of Procedure, Rule IX, 4.: "Representatives of members of subsidiary bodies [i.e. of committees in charge of elaborating the standards before their adoption by the Commission itself] shall, insofar as possible, serve in a continuing capacity and shall be specialists active in the fields of the respective subsidiary bodies.”
} 
countries cannot always afford. ${ }^{37}$ These difficulties speak to the growing concern within developing countries that the Codex is essentially Western-dominated and that Codex standards may be skewed in favor of developed countries' preferences, to the detriment of their sovereign freedom of action. ${ }^{38}$ The Codex has however launched in 2003 a "Codex Trust Fund" that aims to "help developing countries and countries in transition to increase their participation in the vital work of the Commission." ${ }^{39}$ To date, this initiative has however delivered little results as far as the participation of developing countries is concerned. ${ }^{40}$

Second, the Codex Rules of Procedures (Rule VII, 4.) provide that international nongovernmental organizations may be "invited" to "attend as observers sessions of the Commission and of its subsidiary bodies." The observer status allows relevant organizations to "put forward their point of view at every stage except the final decision, which is the exclusive prerogative of member governments." ${ }^{41}$ Concretely, observer status entitles the relevant organization to send representatives and advisers to meetings of the different organs of the Commission, to receive related working documents and discussion papers, to circulate its views in writing to Commission organs, and to participate in discussions when invited by the Chairman. $^{42}$

The "invited" NGOs may be those already associated with FAO or WHO, or international NGOs having a scope of work that is relevant to the work of the Commission. Moreover, the latter NGOs must also have permanent organs and be established at least three years before applying for status. The Directors-General of the FAO and WHO may admit NGOs that do not meet the internationality requirement "if it is clear from their application that they would make a significant contribution to advancing the purposes of the Codex Alimentarius Commission." ${ }^{43}$ FAO- and WHO-linked NGOs are automatically granted observer status when they wish so, while other applicant NGOs must previously submit information about themselves with their application. After that, their application is subject to the advice of the Executive Committee, on the basis of which the Directors-General of the FAO and the WHO will or will not grant status. ${ }^{44}$

The possibilities for participation by Non-Governmental interests in the Codex are rather generous. So far, 161 NGOs have achieved observer status, with a large majority of them representing business interests. ${ }^{45}$ However, the fact that observers do not have the right to vote and therefore lack direct influence on the end-result of the discussion causes many non-governmental organizations to choose to use the channel of their own state representation in order to impact the deliberative process

\footnotetext{
37 D. SCALES, "Contamination and the Codex Alimentarius: Science and Technology in the Regulation of Global Food Markets”, June 17, 2007, available at http://www.yale.edu/ccr/workshop/papers/Codex.pdf.

${ }^{38}$ H. V. MORAIS, “The Quest for International Standards: Global Governance vs. Sovereignty”, 50 U. Kan. L. Rev. 779, 2000-2001, p. 806.

${ }^{39}$ See http://www.who.int/foodsafety/codex/trustfund/en/

${ }^{40}$ D. SCALES, op. cit., pp. 21-22.

${ }^{41}$ CODEX ALIMENTARIUS COMMISSION, Secretariat, Understanding Codex Alimentarius, op. cit., p. 15.

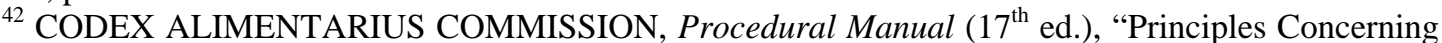
the Participation of International Non-Governmental Organizations in the Work of the Codex Alimentarius Commission”, available at ftp://ftp.fao.org/docrep/fao/005/Y2200E/Y2200E00.pdf,

$\S 5.1$.

${ }^{43} I d ., \S 1$.

${ }^{44} \mathrm{Id} .$, § 4 .

${ }^{45}$ See http://www.codexalimentarius.net/web/organizations.jsp, last visited 14 May 2008.
} 
in the Codex's standard-setting activities. ${ }^{46}$ This is doubly uncertain: their actual participation in the design of Codex standard is indeed conditioned to the willingness of their national representation to take their views into account and to the relative influence of their national representation in the deliberations of the Committees. In practice, it has been shown that the participation of non-governmental organizations (other than representing industry interests) has been extremely reduced, if not entirely anecdotal. ${ }^{47}$

Wide and effective participation in Codex deliberations is therefore far from being guaranteed by the institutional arrangements of the organization. This issue tends to be downplayed given the widespread feeling that the Codex is more of a scientific body than a political one and that the expertise of the participants in the discussion is more important than their representative origin. ${ }^{48}$

\subsubsection{Public interest-oriented character}

The flaws in the Codex' institutional design have serious repercussions on the way the public perceives its public interest-oriented character, and hence, its legitimacy as a regulatory institution, for several reasons.

First, the tendency of the Codex to be captured by corporate interests is very often underlined. The recurring reflex to regard public institutions a priori as pursuing the public interest in regulatory processes, while private actors are seen, a priori as not ${ }^{49}$ acting in such interest must be strongly relativized. Without proper institutional mechanisms and appropriate checks and balances, there is a great risk that public regulatory actors will be captured by particular interests. The Codex is indeed described as "one of the more industry-dominated international organizations" which "corporate capture is institutionalized"51. The purpose of the Codex is indeed for a large part to "codify" the already existing best practices of the industry in terms of safe food. ${ }^{52}$ The industry bias is therefore strongly rooted in the institutional ethos of the Codex. This is confirmed by the fact that the mission of the Codex is twofold: protect consumers' health and facilitate trade. However, it has been argued that in

\footnotetext{
${ }^{46}$ M. A. LIVERMORE, “Authority and Legitimacy in Global Governance: Deliberation, Institutional Differentiation, and the Codex Alimentarius", 81 N.Y.U. L. Rev., 766, 2006, p. 785. With regard specifically to consumer interests, the Codex recognizes explicitly that "[b]ecause of its international nature, the Commission is aware that it can only go part of the way towards involving consumers in its food standardization and related work. Therefore, the Twentieth Session of the Commission invited governments to involve consumers more effectively in the decision-making process at the national level: 'The Commission has continued to involve consumer interests in its work while recognizing that it is at the national level that consumers can make their most valuable and effective input." See CODEX ALIMENTARIUS COMMISSION, Secretariat, Understanding Codex Alimentarius, op. cit., p. 28.

${ }^{47}$ L. WALLACH, "Accountable Governance in the Era of Globalization: the WTO, NAFTA, and International Harmonization of Standards”, 50 U. Kan. L. Rev. 823, 2001-2002, pp. 836-837.

${ }^{48}$ See T. P. STEWART \& D. S. JOHANSON, "The SPS Agreement of the World Trade Organization and International Organizations: The Roles of the Codex Alimentarius Commission, the International Plant Protection Convention, and the International Office of Epizootics”, 26 Syracuse J. Int'l L. \& Com. 27, 1998-1999, p. 28.

49 WORLD TRADE ORGANIZATION, Committee on Sanitary and Phytosanitary Measures, "Considerations relevant to private standards in the field of animal health, food safety and animal welfare, Submission by the World Organization for Animal Health, 25 February 2008, Doc No. G/SPS/GEN/822, p. 1, pt. 4.

${ }^{50}$ J. BRAITHWAITE \& P. DRAHOS, Global Business Regulation, Cambridge, Cambridge University Press, 2000, p. 401.

${ }^{51}$ Id., p. 408.

${ }^{52}$ D. G. VICTOR, "The Sanitary and Phystosanitary Agreement of the World Trade Organization: An Assessment after Five Years”, 32 N.Y.U. J. Int'l L. \& Pol., 865, 1999-2000, p. 889.
} 
pursuing such objectives, the Codex has been more concerned about trade than health issues, thus incurring a "trade bias". ${ }^{53}$

Practically speaking, Codex standards are elaborated by specialized committees, where draft standards are discussed by national delegations. It appears that those national delegations are in fact composed in a large part by industry representatives, giving them direct influence on the debates. ${ }^{54}$ The Codex is also largely funded by industry money, which is "laundered through states" before reaching the organization's accounts. ${ }^{55}$ There is therefore a sustained feeling that Codex as a public organization is in reality pursuing industry objectives rather than the public interest, adding to the suspicion that a number of standards have been set to match the interests of a particular industry. ${ }^{56}$

As previously stated in the last section, the impact of these organizational shortcomings on the public-oriented character of Codex standards may be downplayed by the fact that standardization of food safety requirements is mainly a technical and scientific exercise, and therefore the fact that Codex Committees be populated by experts is regarded as a guarantee against partisan capture. Scientific expertise is indeed the cornerstone of the SPS Agreement, as the WTO itself recently reports,, insinuating that consumer concerns in relation to such or such a product are for a great deal mistaken and based on erroneous information and misjudgment of the actual scientific risk involved. In this context, it is the role of governments to reassure the public that the Codex standard in question is founded on irrefutable scientific findings. ${ }^{57}$ According to a widespread view, thus, the legitimacy of the SPS Agreement harmonization policy would largely result from the fact that it is based on scientific evidence. Such legitimacy claim would then expand to the Codex as a whole. ${ }^{58}$

This view of food safety standards is however largely misleading. Next to the fact that legitimacy in regulatory decision making is not solely a function of expertise, it must be emphasized that deciding upon a food safety standard involves assessing the level of risk posed by a food product, and to make a policy choice about an acceptable level of that risk, to which society may be submitted. That policy choice is clearly not driven by science only, but by social preferences, which may vary geographically and culturally. ${ }^{59}$ Moreover, scientific certainty is not always available in assessing the risks at hand ${ }^{60}$ Furthermore, in certain cases, setting a regulatory food standard may simply not be a question of scientifically deciding upon an acceptable level of risk to health, but rather a question of, say, morals. The debate about Genetically Modified Organisms ("GMOs"), for instance, is not only about whether those products may be unsafe, but also about whether it is appropriate at all to intervene in the genetic code of natural organisms. In such cases, scientific arguments are simply irrelevant. To summarize,

\footnotetext{
53 L. ROSMAN, "Public Participation in International Pesticide Regulation: When the Codex Commission Decides, Who Will Listen?” 12 Va Envtl. L. J. 329, 1992-1993, p. 342.

${ }^{54}$ J. BRAITHWAITE \& P. DRAHOS, op. cit., pp. 407-408.

${ }^{55}$ Id., p. 401.

${ }^{56}$ D. G. VICTOR, op. cit., pp. 887-888.

${ }^{57}$ World Trade Report 2005, p. 158.

${ }^{58}$ T. BÜTHE, “The Globalization of Health and Safety Standards: Delegation of Regulatory Authority in the SPS Agreement of the 1994 Agreement Establishing the World Trade Organization”, 71 Law \& Contemp. Probs. 219 (2008), p. 237-238.

${ }^{59}$ L. WALLACH, op. cit., p. 863.

${ }^{60}$ R. W. HAMILTON, "Prospects for the Nongovernmental Development of Regulatory Standards", 32 Am. U. L. Rev. 455, 1982-1983, p. 455.
} 
"the science used in risk assessment is not a body of knowledge fixed at a particular moment in time through a universally valid expert calculus. Nor is it a body of knowledge arising in isolation from political and cultural values and perfectly transferable across regulatory systems. Rather, sound science in the regulatory sphere needs to be understood as being shaped by the normative priorities, institutional cultures, and collective experiences that influence the framing of risk itself." ${ }^{161}$

The scientific outlook of the Codex and of its standardization activities is therefore no barrier against any "democratic deficit". We shall see in the next section that science, as it is conceived of in the SPS Agreement, is even used as a tool for pursuing the agenda of trade liberalization, even at the expense of food safety issues.

\subsection{The LINKAgE BETWEen the SPS AgREemENT AND SPS StANDARdS IS TOO CLOSE AND RUNS COUNTER TO FOOD SAFETY OBJECTIVES}

The purpose of food safety standard-setting is ultimately to ensure the quality and safety of the food that is offered on the markets. However, when those standards diverge between countries or industry sectors, each individual standard creates difficulties of its own, most notably concerning market access. Consequently, the WTO has decided to attempt to harmonize food standards, that is, to "standardize" food safety standards in order to reduce their negative effects on trade. Ideally, the solution to both issues -food safety and market access and their potential effects upon the overall welfare of society - should be appropriately weighed in the process and with no objective being arbitrarily pursued at the expense of the other. ${ }^{62}$

This is however not the case with the SPS System and the linkage between the food standards and trade has resulted in the latter taking over the former. Indeed, while it is somewhat concerned by issues of food health and safety, the SPS Agreement is nothing but a trade agreement, and as such, its objectives are not to increase the general level of food health and safety, but to harmonize SPS measures - upwards or downwards is not the matter - in order to pursue the trade liberalization agenda. In order to make the harmonization movement as wide and effective as possible, the SPS Agreement designates international organizations the standards of which are made references for compliance with it. In other words, if a food safety standard effective in a country "conforms" to a Codex standard, it is deemed not to violate the liberalization objective enshrined in the SPS Agreement (Art. 3.1.). If the national regulation is more stringent than an existing Codex standard, such deviation must be justified scientifically (Art. 3.3.). On the contrary, if a national standard is less protective of health than a Codex standard, this is perfectly fine for the SPS Agreement. In fact, if a WTO member state decided to abrogate at once all its food safety regulations and other SPS measures, even causing its population to be exposed to significant health risks, this would also be fine. ${ }^{63}$

The structure of the SPS Agreement is therefore making Codex standards play the role of a de facto ceiling for SPS measures ${ }^{64}$, and actually, in case of conflict the free

${ }^{61}$ D. WINICKOFF, S. JASANOFF, L. BUSCH, R. GROVE-WHITE \& B. WYNNE, “Adjudicating the GM Food Wars: Science, Risk, and Democracy in World Trade Law”, 30 Yale J. Int'l L. 81, 2005, p. 106.

62 See D. KALDERIMIS, "Problems of WTO Harmonization and the Virtues of Shields over Swords", 13 Minn. J. Global Trade 305, 2004, pp. 335 ff.

${ }^{63}$ Id., p. 338.

${ }^{64}$ J. BRAITHWAITE \& P. DRAHOS, op. cit., p. 411, nonetheless write that to date (2000), there has not been a race to the bottom, and that even, "standards may have been harmonized up rather than down". We would in turn argue that, even if the overall level of food standards may have risen, the structure of the SPS Agreement will de facto prevent standards exigencies to rise above Codex 
trade values often trump the health values that may be present in a stringent national food safety regulation. We have seen that the scientific basis that constitutes the requirement to justify a more stringent food standard was sometimes of little help to defend a national regulation: either that the country in question does not have the resources to procure, produce or present such evidence; or that the regulation in question is founded on other grounds than a scientific risk assessment; or that available scientific evidence does not (yet) fully support the regulation at hand. ${ }^{65}$ In the light of the vital interests that may be protected by food standards, that quasiobsession for scientific justification sounds itself rather difficult to justify: either the WTO is naïve or misinformed in believing that science has all the answers when it comes to food safety ${ }^{66}$, or it instrumentalizes science in its pursuit of free trade against healthy food. As Steve Charnovitz puts it "[t]he WTO demands science to justify sanitary measures that impede trade, but it seeks no science to justify commercial measures that impede trade, such as antidumping duties. This selective use of science undermines the WTO's claim that it is operating in the public interest." 67

Even as the states are willing to come before the dispute settlement body of the WTO ${ }^{68}$ in order to defend their SPS measures in light of scientific arguments, the practice has shown that that was in most cases unsuccessful. Of all five cases that were litigated before the WTO dispute settlement panels and appellate body in relation to the SPS Agreement, none were ruled in favor of the standard-setting country. ${ }^{69}$ In such disputes, the settlement authorities generally put emphasis on the trade-friendly scientific justification and risk assessment requirements laid on SPS measures, whereas they largely disregarded the extent to which such measures could be induced by widely shared desiderata in the public opinion. ${ }^{70}$ This particular inflexibility may be linked with the natural fact that WTO institutions, including the dispute settlement body, are organs dedicated to the promotion of free trade, and therefore suffer from a trade bias, which impacts other policies when it crosses them. Indeed, when a trade organization "enters new areas where other objectives and interests play an important role [e.g. the food safety regulation sector], the trade bias

requirements, even if that may be required from a public policy point of view. See L. WALLACH, op. cit., p. 831: "Because domestic standards that do not conform to international standards must satisfy a battery of [...] WTO tests in order to avoid being considered barriers to trade, the burden of proof falls on the country defending a stronger domestic health or environmental law. Thus, the pact[...] create[s] significant incentive for the countries to avoid exceeding international standards.”

${ }^{65}$ See, about the precautionary principle, SPS Agreement, Article 5.7.

${ }^{66}$ See the "technocratic" approach to standardization, which tends to consider that all divergence in standards must be due to protectionist or irrational motives: H. SCHEPEL, The Constitution of Private Governance - Product Standards in the Regulation of Integrating Markets, Oxford \& Portland, Hart Publishing, 2005, p. 6.

${ }^{67}$ S. CHARNOVITZ, “The Supervision of Health and Biosafety Regulation by World Trade Rules", 13 Tul. Envtl L. J. 271, 1999-2000, p. 301.

${ }^{68}$ Which many states are not, due to the high costs of the arbitral procedure. This is another incentive for states to comply blindly with Codex standards without searching for the optimal level of food protection that is desired by their population.

${ }^{69}$ See the Australia - Measures Affecting Importation of Salmon cases (cases Nos. DS18 \& DS21); the European Communities - Measures Concerning Meat and Meat Products (Hormones) cases (cases Nos. DS26 \& DS48); the Japan - Measures Affecting Agricultural Products case (case No. DS76); the Japan - Measures Affecting the Importation of Apples case (case No. DS245); and the European Communities - Measures Affecting the Approval and Marketing of Biotech Products cases $\begin{array}{llllll}\text { (cases Nos. } 292 & 291, & 293\end{array}$ available http://www.wto.org/english/tratop_e/dispu_e/find_dispu_cases_e.htm

${ }^{70}$ For a thorough analysis of the extent to which public opinion has been a decisive factor in WTO dispute settlement in respect of national SPS measures, see C. E. FOSTER, "Public Opinion and the Interpretation of the World Trade Organization's Agreement on Sanitary and Phytosanitary Measures”, 11:2 Journal of International Economic Law 427, 2008. 
may serve to distort the final outcome of the negotiation and tip the scales toward trade objectives at the expense of other goals and values." ${ }^{11}$

The WTO is indeed a very effective and powerful organization, notably resulting from its mandatory and well-functioning dispute settlement mechanism. In the context of the SPS Agreement, the WTO dispute settlement mechanism serves as a weapon for the subjection of food safety standards to free trade disciplines, with no alternatives for dispute resolution. In legislating by proxy in the food domain and in enforcing the ensuing norms against democratic national regulations, the WTO is de facto creating a sort of hierarchy of the norms, with the rules of free trade at the top. ${ }^{72}$ This is perceived by many as a worrisome overstepping of its mandate by the WTO. ${ }^{73}$

The linkage between the SPS Agreement and Codex standards has had another perverse effect. Indeed, by giving Codex standards a "quasi-legislative" value in international law ${ }^{74}$, when originally intended as voluntary, the linkage has strained the deliberative climate in the Codex itself. As the adoption of Codex standards is likely to have a direct impact on WTO members' international obligations, it may be said that the latter's trade agendas are polluting the adoption procedures for standards, and pressuring the preference for consensus in adopting Codex standards. ${ }^{75}$ By this connection an increase in voting in the adoption of standards in case of non-consensus has been observed since the adoption of the SPS Agreement. ${ }^{76}$ The linkage therefore resulted in standards which are less representative of a wide consensus and potentially less protective for health than many national legislations were made internationally mandatory. This may hardly be regarded as a socially optimal outcome to the problem of unhealthy food. As a result, one can conclude that, if it proves generally effective to reach free trade objectives, the SPS Agreement is unsatisfactory as an instrument for the maintenance of high food safety standards. Therefore, by organically linking the pursuit of trade liberalization with food safety standards, the SPS Agreement creates imbalance between free trade and food safety. In other words, by attempting to harmonize (or standardize) SPS measures, and by backing that process with its powerful enforcement mechanism, the SPS Agreement prefers to solve the free trade issue than the food safety issue. We doubt that such a structurally organized preference for the value of free trade over health is really in the public interest.

\section{Alternatives to Public Standardization of Food Products by the Codex: THE CASE FOR OR AGAINST PRIVATE STANDARDS}

In the previous sections we have established that food standardization by a public body such as Codex is unsatisfactory in terms of effectiveness and legitimacy, especially in its organic link to the trade liberalization agenda by means of the SPS Agreement. In fact, Codex standards no longer pursue the objective of ensuring that only safe food reaches markets, but rather seek to constrain national food-related legislations which would rise above a certain level, regardless of social preferences. This has been characterized by certain authors as a breach of the underlying pact

\footnotetext{
${ }^{71}$ A. REICH, “The WTO as a Law-Harmonizing Institution”, 25 U. Pa. J. Int'l Econ. L. 321, 2004, p. 365.

72 See D. KALDERIMIS, op. cit., p. 314.

73 See L. WALLACH, op. cit., p. 827.

${ }^{74}$ G. MARCEAU \& J. P. TRACHTMAN, op. cit., p. 838.

${ }^{75}$ T. P. STEWART \& D. S. JOHANSON, op. cit., pp. 52-53.

76 See A. HERWIG, "Legal and institutional aspects in the negotiation of a Codex Alimentarius Convention”, Zeitschrift für das gesamte Lebensmittelrecht, 2/2001, p. 260.
} 
that was at the root of the international trade regime: the pursuance of "embedded liberalism", that is, the constant concern for the appropriate balancing of the "efficiency of markets with the values of social community that the markets themselves require in order to survive and thrive." ${ }^{\prime 77}$ Indeed, the structure of the SPS Agreement is designed in such a way that free trade values will in most cases trump health considerations. We have noted that such shortcomings were notably due to the fact that the Codex was a public international organization, and that its institutional design was not appropriate to produce effective and legitimate regulations.

In light of the many purely private initiatives that are developing in the field of food safety standardization, we now question whether, and under what conditions, private standards would be more likely to successfully meet the food safety challenge than the Codex is, while still being able to advance (or at least not constrain) the free trade agenda. In doing so, we shall focus our study on the GLOBALG.A.P. initiative.

\subsection{The Debate about Private Standards and Free Trade at the WTO}

Private standards in the food sector are typically developed by business actors such as associations of large retailers, which contractually impose compliance with their standard to their suppliers. Such standards may pertain to characteristics of the products themselves, or to "process and production methods" ("PPMs"), that is, "the way in which products are manufactured or processed and natural resources harvested or extracted." Most of these standardizing schemes require that producers get their products certified in order to demonstrate compliance with the standard. Private standards in relation to international trade law are usually regarded as problematic in the context of the free trade agenda as they tend to add new knots to the already complex web of market access restrictions. This is especially true for small producers in developing countries, which often do not have either the expertise to comply with the requirement of the standard, or the financial ability to obtain an often costly certification. ${ }^{79}$ As private standards may set requirements higher than Codex standards and challenge the universality of the latter, they are generally considered to be at odds with the SPS Agreement disciplines. ${ }^{80}$ It is also alleged that private standards are often not based on scientifically backed risk assessments. ${ }^{81}$ Article 13 of the SPS Agreement notably states that "Members shall take such reasonable measures as may be available to them to ensure that non-governmental entities within their territories [...] comply with the relevant provisions of this

\footnotetext{
${ }^{77}$ J. G. RUGGIE, “Taking Embedded Liberalism Global: The Corporate Connection”, IILJ Working Paper 2003/2, History and Theory of International Law, available at http://www.iilj.org/publications/documents/2003.2\%20Ruggie.pdf, p. 1; see also R. HOWSE, "From Politics to Technocracy - And Back Again: The Fate of the Multilateral Trading Regime”, 96 Am. J. Intl'l L. 94, 2002, pp. $96 \mathrm{ff}$.

${ }^{78}$ See generally ORGANIZATION FOR ECONOMIC CO-OPERATION AND DEVELOPMENT, "Processes and Production Methods (PPMs): Conceptual Framework and Considerations on the Use of PPM-Based Trade Measures", Doc. No. OECD/GD(97)137, 1997, available at http://www.olis.oecd.org/olis/1997doc.nsf/LinkTo/NT0000299E/\$FILE/08E73097.PDF.

${ }^{79}$ G. CHIA-HUI LEE, "Private Food Standards and their Impacts on Developing Countries", European Commission - DG Trade Unit G2 Paper, 2006, available at http://trade.ec.europa.eu/doclib/docs/2006/november/tradoc_127969.pdf.

${ }^{80}$ See the experience of the farmers of the small Caribbean island of St Vincent and the Grenadines with EurepGAP (now GLOBALG.A.P.): WORLD TRADE ORGANIZATION, Committee on Sanitary and Phytosanitary Measures, "Private Industry Standards", Communication by Saint Vincent and the Grenadines, February 27, 2007, Doc No. G/SPS/GEN/766.

${ }^{81}$ WORLD TRADE ORGANIZATION, Committee on Sanitary and Phytosanitary Measures, "Private Standards and the SPS Agreement”, Note of the Secretariat, January 24, 2007, Doc. No. G/SPS/GEN/746, p. 4.
} 
Agreement." It is also argued that private food safety standards may violate in a number of ways the Code of Good Practice of the TBT Agreement, about which the Member states have committed to take reasonable measures in order to ensure compliance by non-governmental bodies. Accordingly, developing countries have repeatedly called for a more vigorous application of these provisions, but it is still unclear what is actually expected from the Member States under those provisions, and what the outcome of the debate will be. ${ }^{82}$ Indeed, private standards as they are integrated in commercial contracts between producers, retailers and consumers are in essence a matter of private law, and one does not really see how the SPS and TBT disciplines could have any direct leverage upon those private transactions. ${ }^{83}$

The debate is further complicated by the fact that the WTO itself recognizes certain merits to private standards. As they respond to consumer concerns and expectations (at least in developed countries) and address market failures, such as externalities, and problems of imperfect information, such private standards are likely to boost trade in a number of sectors. ${ }^{84}$ In that connection, the EU, from where a number of those private standards originate, seems reluctant to take any measure to reduce the influence of private standardization schemes ${ }^{85}$ Moreover, private standards, as they use powerful commercial levers to impose themselves (e.g. supply agreements), and as they require certification, are likely to induce producers, especially in developing countries, to modernize and rationalize their production practices as a result of their applying for the standard. ${ }^{86}$

\subsection{PRIVATE Standards ANd REgulation of FoOd PRODUCtS}

In this section, we shall address whether, from a normative point of view, private standards are better fitted than the Codex to achieve effective, public interestoriented and legitimate international food safety regulation in the context of the free trade agenda. In doing so, we will focus on a very pervasive standardization scheme, focused on agricultural products and "Good Agricultural Practice" ("G.A.P."): GLOBALG.A.P.

\subsubsection{Presentation of GLOBALG.A.P.}

GLOBALG.A.P was founded as EurepGAP in 1997 by the Euro-Retailer Produce Working Group (EUREP). Its European scope was extended to the globe in September 2007. GLOBALG.A.P. is thus a private initiative owned by the food industry. Membership to the organization is open to all relevant food retailers, producers and suppliers which agree to the terms of reference of the organization

\footnotetext{
${ }^{82}$ G. H. STANTON, "Private (Commercial) Standards and the SPS Agreement", Submission at the Round Table on The Role of Standards in International Food Trade, Washington, D.C., September 24, 2007, available at http://www.agritrade.org/events/documents/PrivatestandardsandSPSAgreement.doc, p. 6.

${ }^{83}$ S. HENSON, op. cit., p. 28: "[t]he WTO has no jurisdiction there." See also WORLD TRADE ORGANIZATION, COMMITTEE ON SANITARY AND PHYTOSANITARY MEASURES, "Private Voluntary Standards Within the WTO Multilateral Framework", Submission by the United Kingdom of 9 October 2007, WTO Doc. No. G/SPS/GEN/802, pp. 54-55.

${ }^{84}$ Id., p. 3.

${ }^{85}$ At the meeting of the SPS Committee of June 29-30, 2005, dedicated to the issue of private standards, "[t]he EU said it is not in a position to intervene because the private sector organizations say they are reflecting consumer demand. [...] If any of these claim the standards are EU standards, then WTO members should take this up with Brussels, the EU said. Otherwise the concerns should be raised with the non-governmental organizations concerned, it said." See SPS Committee news release of June 29-30, 2005: "Private sector standards discussed as SPS Committee adopts two reports", available at http://www.wto.org/english/news_e/news05_e/sps_june05_e.htm.

${ }^{86}$ G. CHIA-HUI LEE, op. cit., p. 23.
} 
(see infra, this section). Membership is divided into three groups, retailers, producers/suppliers and associates (i.e. members engaged in activities related to the food industry or exercising standardization-related activities).

Governance of GLOBALG.A.P. is led by a Board, which "agrees on the vision and short- and long-term activity plan of the organization." ${ }^{87}$ It is elected by the retailer and producer/supplier members. The day-to-day management of the organization and implementation of the standards is ensured by a Secretariat, incorporated as a German not-for-profit company, FoodPlus $\mathrm{GmbH}$, which may legally represent the organization. ${ }^{88}$ The GLOBALG.A.P. standard itself is elaborated by "Sector Committees" elected by the retailer and producer/supplier members. The Sector Committees each work on the technical aspects of specific sub-scopes of the GLOBALG.A.P. standard. ${ }^{89}$ There is also a "Certification Body Committee", composed of certification bodies that are members of GLOBALG.A.P. The Certification Body Committee is there to harmonize the varying interpretations of the standard that may arise in the more than 100.000 yearly audits. ${ }^{90}$

The terms of reference of the organization are:

"[t]o respond to consumer concerns on food safety, environmental protection, worker health, safety and welfare and animal welfare by:

(i) Encouraging adoption of commercially viable farm assurance schemes, which promote the minimization of agrochemical and medicinal inputs, within Europe and worldwide.

(ii) Developing a Good Agricultural Practice (G.A.P.) framework for benchmarking existing assurance schemes and standards including traceability.

(iii) Providing guidance for continuous improvement and the development and understanding of best practice.

(iv) Establishing a single, recognized framework for independent verification.

(v) Communication and consulting openly with consumers and key partners, including producers, exporters and importers." ${ }^{\prime 1}$

As such, GLOBALG.A.P. develops one standard: the "Integrated Farm Insurance Standard", which is product-oriented and contains requirements specific to each concerned agricultural product group. The concerned product groups are crop products, livestock products and aquaculture products. The products covered are therefore only primary agricultural products. The standard addresses issues pertaining to plant and livestock production, plant propagation materials and compound feed manufacturing. ${ }^{92}$ In GLOBALG.A.P.'s own words, the standard is "a pre-farm gate standard that covers the whole agricultural production process of the certified product from before the plant is in the ground (origin and propagation material control points) or from when the animal enters the production process to non-processed end-product (no processing, manufacturing or slaughtering is covered)."

\footnotetext{
${ }^{87}$ GLOBALG.A.P., “General Regulations - Integrated Farm Assurance, Part I - General Information”, September 2007, available at http://www.ikc-um.si/ikc-datoteke/general\%20regulations\%20\%20splosna\%20pravila\%20-\%20ENG_V3_0_2_Sep07.pdf, p. 9. (Hereinafter “General Regulations”)

${ }^{88}$ See http://www.globalgap.org/cms/front_content.php?idcat $=15$

${ }^{89}$ General Regulations, p. 10.

${ }^{90}$ See http://www.globalgap.org/cms/front_content.php?idcat=22

${ }^{91}$ General Regulations, pp. 7-8

${ }^{92}$ See http://www.globalgap.org/cms/front_content.php?idcat=3
} 
The actual procedure of definition of new GLOBALG.A.P. standards or of new product-specific modules for the existing standard involves adoption of the project (after consultation of the stakeholders) by consensus at Board level, followed by a public review phase of said standard/module project, and discussions at the Sector Committee level, taking into account public comments. Sector Committees normally decide by consensus, but may vote in the absence of consensus. Draft standards approved by the relevant Sector Committee and by the Board are then subject to a new public comment phase, to correct "technical errors", after which standards become final. Standards are normally revised every four years to ensure continued relevance and effectiveness. The adoption procedures for GLOBALG.A.P. standards state that "[p]articipation in the standard-setting procedures of GLOBALG.A.P. is open for interested parties in the subject matter. Balance of interested representatives is always promoted between producers and retail/food service organizations." ${ }^{93}$

Producers of relevant primary agricultural products may apply for certification, which is given by approved certification bodies after several on-site inspections. ${ }^{94}$ The objective of GLOBALG.A.P. certification is to form part of the verification of Good Practices along the whole production chain. ${ }^{95}$ An elaborate system of sanctions and appeals is also put in place for cases of non-conformance with the standard. ${ }^{96}$

The GLOBALG.A.P. certificate of compliance is valid for twelve months ${ }^{97}$, and maintenance of the certification implies that the full process must be renewed each year. ${ }^{98}$ The cost of the procedure must be borne by the producer, and often implies significantly upgrading the farm in order to become compliant. The financial burden of such improvements can be very high, especially for small producers. ${ }^{99}$ Once the farm is compliant, the certification cost for the product itself is however reasonable in relation to sales, and amounts to a few percents of the sale price per product. ${ }^{100}$ GLOBALG.A.P. is aware of the difficulties that small farming exploitations may have in the certification process, and it has therefore developed a "Smallholder Involvement" program. Under that program, GLOBALG.A.P. has issued a specifically crafted "Smallholder Manual", which constitutes a starting point for producers who would like to get certified. Also, smallholders can apply for group certification in order to reduce their individual certification costs. Finally, GLOBALG.A.P. wants to include the situation of smallholders into the future developments of the standard, and therefore has set up a "Smallholder Task Force"101 and appointed an observer for Africa, who will report on those issues. ${ }^{102}$

\footnotetext{
${ }^{93}$ GLOBALG.A.P., Procedures for the Setting and Revision of GLOBALG.A.P. Standards, August 2008, available at http://www.globalgap.org/cms/upload/The_Standard/IFA/English/Guidelines-SuppDocs/GLOBALGAP_Standard_setting_procedure_V1_Aug08.pdf.

${ }^{94}$ See a description of the Certification process at General Regulations, p. 16

${ }^{95}$ General Regulations, p. 8.

${ }^{96}$ Id., pp. $28 \mathrm{ff}$.

${ }^{97}$ Ibid., p. 20.

${ }^{98}$ Ibid.. p. 23

${ }^{99}$ WORLD TRADE ORGANIZATION, Committee on Sanitary and Phytosanitary Measures, "Private Voluntary Standards and Developing Country Market Access: Preliminary Results”, Communication from the OECD, February 27, 2007, Doc. No. G/SPS/GEN/763, pp. 3-4.

$100 \quad$ Id., and GLOBALG.A.P. General Fee Table 2008, available at http://www.globalgap.org/cms/upload/The_Standard/IFA/English/Guidelines-Supp-Docs/GENERALGLOBALGAP-FEE-TABLE-2008_230408.pdf, pp. 1-6.

${ }^{101}$ See http://www.globalgap.org/cms/front_content.php?idart=299\&idcat=70\&lang=1\&client=1

102 See http://www.globalgap.org/cms/front_content.php?idcat=70
} 


\subsubsection{Assessment of GLOBALG.A.P. from an Effectiveness and Legitimacy Perspective}

First of all, GLOBALG.A.P. is likely to be very dynamic and effective in response to changing public preferences regarding food safety. As the purpose of the standard is expressly to satisfy consumer expectations, and as the profits of its members depend on those expectations being satisfied, GLOBALG.A.P. will certainly closely observe how consumer preferences evolve over time and adapt its standard accordingly. From that point of view, GLOBALG.A.P. is certainly in a better position than the country representatives that elaborate Codex standards, even if the latter are in close contact with the industry.

In addition, the fact that GLOBALG.A.P. must cohabit with other quality schemes on the food products market makes private standards for food safety a source of product differentiation that plays a role in the competition between food products. That competition between standards is also a source of continuous improvement of the standards, and of constant research of consumer preferences. ${ }^{103}$

In that connection, one must therefore reconsider the widespread feeling that private actors, and especially business actors which seek profit, are unlikely to set high standards, and that public regulation must therefore be preferred. In fact, in certain circumstances private actors set standards that are higher than public regulations. This is notably the case on food products markets, where consumers demand high standards and where they are able to shift very rapidly and easily from one product/producer/retailer to another in case their expectations are not satisfied. Business actors on the food products markets have therefore every incentive to set high standards. Quite ironically, it is now rather public regulators in the field of free trade that demand lower standards. Where the market, like the food products market, is effective to implement social values because they match with consumer preferences and, hence, economic success, private actors are certainly as well positioned as public actors in setting effective and high standards that are directed at the public interest. ${ }^{104}$

With regard to the legitimacy of private food standards, and more precisely to issues of participation and accountability, one must note that the regulation of food markets is increasingly influenced by the voice of civil society, whose demands in relation to food products increase constantly. ${ }^{105}$ The fact that the GLOBALG.A.P. standard includes elements such as environmental protection, worker health, safety and welfare and animal welfare in addition to food safety illustrates that trend. GLOBALG.A.P. is committed to meeting consumer preferences and may be sanctioned by consumers in case of misperformance. This may give the impression that GLOBALG.A.P. is accountable to civil society, and therefore lay a veil of legitimacy on the standard. One must however not confuse consumer interests with civil society interests or the public interest in general. The interests of the body of consumers, as it is a priori composed of the whole society, is certainly a very important component of the public interest. However, as GLOBALG.A.P. is owned by essentially western retailing groups, the consumers they address are also mostly western. The problem is that, the food products market being integrally global, the activity of the GLOBALG.A.P. constituencies have effects on a much wider public than simply western consumers, most notably on producers of developing countries.

\footnotetext{
103 See S. HENSON, op. cit., p. 14.

104 See, to that effect, T. HAVINGA, “Private Regulation of Food Safety by Supermarkets”, 28 Law \& Policy 515 (2006), p. 520.

105 WORLD TRADE ORGANIZATION, Committee on Sanitary and Phytosanitary Measures, "Private Voluntary Standards and Developing Country Market Access: Preliminary Results", Communication from the OECD, op. cit., p. 1.
} 
As a result, a real public-oriented private standard-setting initiative in the food sector should not only pursue the economic interests of its members by pleasing its consumers, but should take account of its role of "public" regulator and of provider of social welfare. That implies notably to strive for legitimacy by ensuring that all relevant interests will have been appropriately weighed at the end of a democratic regulatory process.

The primary principle in this respect is that of participation: all impacted constituencies of society (and, in this global context, this means the global society) must be given a chance to participate in regulatory processes that will affect them. ${ }^{106}$ It is true that the conditions of membership of GLOBALG.A.P. are very open, and that any producer, supplier or retailer may adhere and be elected to the board or to sector committees, which are equally composed of representatives of retailers and producers/suppliers. We have already noted, however, that small producers from developing countries were unlikely to have the ability to effectively participate in the rule-making process. The yearly membership fee, for example, can be a deterrent to joining. ${ }^{107}$

Also, civil society and stakeholder constituencies, like consumer groups, are not formally represented in the management of GLOBALG.A.P., and only retailer and producer/supplier members can be elected to Sector Committees. GLOBALG.A.P. however claims that "[t]o ensure global acceptance GLOBALG.A.P. actively engages with many different stakeholders around the globe", and that it "welcomes proposals and recommendations from all relevant parties to feed into its standard development" ${ }^{\prime 108}$. Stakeholder consultations and public notice-and-comment phases in the development of standards are indeed part of the GLOBALG.A.P. standardsetting procedure. Participation is also made operative by the establishment of "National Technical Working Groups", which are established nationally at the initiative of national GLOBALG.A.P. members. The purpose of those working groups is to develop local guidelines for the application of the standard where it needs adaptation to local circumstances, as well as to gather input from local experts and other stakeholders "with respect to the differing legal and structural conditions that exist globally". Whereas in the past, the vast majority of National Technical Working Groups was being established in developed countries, more and more of such entities are being set up in developing countries that are large exporters of agricultural products. ${ }^{109}$

More stakeholder consultation takes place in the Certification Body Committee, where associate members, including stakeholders joining on a voluntary basis, may be elected. It seems however that, as its name indicates, the Certification Body Committee is mostly populated by certification bodies which report on the technical issues that have arisen in the exercise of their certification activities. Input and participation from consumers, workers, or other relevant actors therefore only takes place at the margins, through notice-and-comment procedures, but not in the actual adoption decision. Stakeholder participation may also affect the GLOBALG.A.P. standard a posteriori, at the interpretation and feedback stage. As GLOBALG.A.P. itself states, "associate members [i.e. potentially stakeholders] have a significant influence on the GLOBALG.A.P. standard-setting process, without being directly involved in decision making." ${ }^{\text {110 }}$ From a legitimacy point of view, this reduced

\footnotetext{
106 G. DE BÚRCA, op. cit., p. 253.

${ }^{107}$ See the GLOBALG.A.P. General Fee Table 2008, op. cit., p. 7.

108 See http://www.globalgap.org/cms/front_content.php?idcat=22. See also point (v) of the terms of reference of GLOBALG.A.P.

${ }^{109}$ See http://www.globalgap.org/cms/front_content.php?idcat=21

110 See http://www.globalgap.org/cms/front_content.php?idcat=25
} 
embeddedness of stakeholder participation in the adoption and definition of the standard does not seem to coincide with the huge impact that the standard may have on them and can thus be analyzed as a democratic deficit.

Moreover, as a Business-to-Business (B2B) standard, GLOBALG.A.P. is primarily intended to be used in business transactions and across supply chains. It is therefore not directly visible to consumers and other stakeholders ${ }^{111}$, contrary to the public standards subject to the SPS Agreement, which have to be notified to other WTO member states. ${ }^{112}$ This creates another bias in favor of a strictly businessoriented, and not public-oriented standard. That relative lack of transparency may therefore also have repercussions on the accountability of GLOBALG.A.P. on the actors affected by its regulations and which do not have access to the B2B loop.

Finally, systematic cooperation and consultation with relevant public bodies is also not an imediate concern for GLOBALG.A.P. As a transnational regulatory actor whose rules may interfere with other public norms and objectives, such as development programs, for example, GLOBALG.A.P. should consider coordinating with other public actors in order to ensure that its standards do not run counter to other legitimate agendas. In relation to the trade liberalization agenda, another public purpose with which it potentially interferes, GLOBALG.A.P. seems to be aware of the impact of its standard on market access for products of small producers in developing countries, and of the criticism that it raises in the WTO ambit. This is why GLOBALG.A.P. has attended meetings of the SPS Committee in order to discuss the issue. ${ }^{113}$ In the next subsection, we shall evaluate how the potentially trade-distorting effects of GLOBALG.A.P. could be addressed.

\subsubsection{GLOBALG.A.P. and the Trade Issue}

Private standards have over public standards the advantage of being able to develop autonomously with regard to regulations in other fields, provided they comply with the relevant public legislation in force. ${ }^{114}$ This avoids forced "linkages" such as the one between the SPS Agreement and Codex standards, which creates a de facto hierarchy between free trade values and food safety standards. Such disconnection is however not necessarily optimal. Free trade is indeed a respectable objective, and potentially carries great economic and social benefits. Therefore, just as the SPS Agreement is arguably illegitimate when it pursues trade liberalization at the expense of food safety, GLOBALG.A.P. would be illegitimate in pursuing its food safety standardization activity without being mindful of its impact on trade.

Conscious that the blossoming of multiple private standard setting schemes may have impeding effects on trade, GLOBALG.A.P. has the ambition to "establish ONE standard for Good Agricultural Practice (G.A.P.)."115 The fierce competition that exists between products using standardization schemes, and the fact that those schemes have become a factor of differentiation between products may lead in certain circumstances to a de facto harmonization of practices, if a standard imposes itself as dominant on the market. GLOBALG.A.P. is undoubtedly one of the dominant actors on the private food standardization market, and it is determined to enhance

\footnotetext{
111 General Regulations, p. 8

112 See SPS Agreement, Article 7 and Annex B.

113 See SPS Committee news release of February 28, 2007 and March 1, 2007: "Private standards are a mixed blessing, committee hears”, available at http://www.wto.org/english/news_e/news07_e/sps_28feb_1march07_e.htm.

114 See C. SCOTT, "Private Regulation of the Public Sector: A Neglected Facet of Contemporary Governance”, 29 J. L. \& Soc. 56, 2002, p. 58.

${ }^{115}$ See http://www.globalgap.org/cms/front_content.php?idcat=2 (emphasis in original).
} 
the harmonizing trend through a mechanism of "benchmarking", which allows other food product standardization schemes that comply with GLOBALG.A.P. to obtain official recognition of that equivalence with GLOBALG.A.P. and therefore reduce the number of certifications that would be required of a product in order to enter on different markets applying different standards. ${ }^{116}$ According to certain authors, benchmarking would be very effective and a "process of harmonization and mutual recognition has occurred in response to the growing dominance of [GLOBALG.A.P.] in supply chains for fresh produce, arguably at a much faster rate than would occur with [public] regulatory requirements." 117 The competition that exists between private standard-setters would therefore be a stronger harmonization tool for the free trade agenda than the appointment of a country- and expert-driven international organization.

\section{CONCLUSION}

We now stand in front of a triple puzzle: there are two potentially conflicting and equally important transnational regulatory agendas: free trade and food safety; there are two potentially conflicting models of food safety regulation: public and private; and there are two potentially conflicting groups of regulatory values: dynamism and effectiveness on the one hand, and democracy and legitimacy on the other hand. How then are we to build a transnational food safety regulatory model that reconciles these conflicting principles - a model which does not advance one principle at the expense of another? In other words, can the optimal social and economic regulatory balance be struck, and how?

In previous sections, we have seen that the current articulation of a public international treaty, the SPS Agreement, with a government-based food safetyfocused standardization body was not optimal: the linkage between the free trade and food safety agenda is too close and subjects the latter to the former. Also, the designation of one public standardization body - the Codex Alimentarius Commission - as the universal reference for food safety risks halting the dynamics of the standard-setting process, possibly engendering a disconnection between the standards and subsequent social or (bio)technical evolutions. Finally, we have seen that the institutional design of the Codex was not optimal from a legitimacy point of view, as the participation of civil society and of developing countries as a whole is not guaranteed by the facts, and as its accountability to the general public is therefore limited. In short, all these factors create imbalance in favor of free trade and business values against food safety and the general interest.

From our analysis of GLOBALG.A.P., we could see that there is a strong potential in private food safety standardization schemes to successfully address these concerns. ${ }^{118}$ Private food safety standards are indeed very close to consumer markets and very reactive to evolutions in food safety conditions, which are becoming increasingly brutal and sudden, as witnessed by the recent food crises in the EU and the US. We have also seen that, in terms of legitimacy, the record of private initiatives such as GLOBALG.A.P. was probably not any darker than that of public institutions like the Codex: there are participation schemes for civil society actors and stakeholders and a possibly strong accountability relationship toward consumers. However, those participation and accountability principles should be truly embedded in a democratic decision-making process, rather than being

\footnotetext{
${ }^{116}$ See http://www.globalgap.org/cms/front_content.php?idart=44\&idcat=29\&lang=1\&client=1

117 S. HENSON, op.cit., p. 22. See also Id., pp. 16 \& 25.

118 For examples of effective private regulation of public interest domains, see K. RONIT \& V. SCHNEIDER, “Global Governance through Private Organizations”, 12:3 Governance 243, July 1999.
} 
marginally confined to notice-and-comment-oriented stakeholder consultation. Accordingly, such private standard setters must become accountable not only to the consumer market (which represents their commercial target), but also to other constituencies that their standards affect, such as the producers. In short, when they have the ambition to regulate a public interest like food safety, private standardsetting organizations must strive for a very high degree of legitimacy toward the public at large. Moreover, if their regulatory ambitions are transnational, their legitimacy must also take a transnational form, and requires engaging with civil society on a transnational basis.

Is this to say that private actors should in all instances be preferred to public actors in the transnational food safety agenda? Certainly not: we have seen that in the reflexive regulatory model, public authorities retained very important functions, as depositaries of the public interest and guarantors of the democratic process. Private regulation, even if it ensures broad and effective participation to all stakeholders, cannot be left to its own devices, but must be monitored for legitimacy, public accountability and effectiveness, and be positively steered toward the general interest. One must be wary, as Richard Steward rightly points out:

"[of the] temptation to equate governance arrangements based on stakeholder interest representation with democratic government. We must also be mindful of the risk that providing too great a role for stakeholder representatives could compromise the ability of international regimes to successfully carry out their primary functions. Here again the tension between accountability and efficiency presents itself." 119

But what should then be the modalities of the public intervention in the food safetyfree trade puzzle? As we have seen, public initiatives in food safety should not be organically linked to another agenda, as it is presently the case: a trade agreement, the SPS Agreement, designates Codex as the relevant standard-setting body in the area of food safety, hoping to harmonize standards in that sector, and hence reduce regulatory barriers to trade. If that strategy may be successful for the free trade agenda, we have seen that it was potentially very harmful for the food safety objective, as free trade, using the bite and power of the WTO, has the ability to override ambitious food safety regulations. The two agendas should therefore be allowed to be pursued more autonomously (though not in complete isolation) and each contain safeguards in case of encroachment by the other. The trade agenda could lay and enforce a strict prohibition of protectionist or unnecessarily traderestricting food safety standards, and in turn, the food safety agenda could claim an a priori deference of the free trade agenda to food safety standards, even if they hinder international trade, when they are based on a non-illegitimate motive. ${ }^{120}$ In that connection systematic recourse to scientific justification should in any case be abandoned as a free-trade oriented harmonization tool, and cultural or precautionary justifications should be admissible as a matter of principle. ${ }^{121}$

\footnotetext{
${ }^{119}$ R. STEWART, op. cit., p. 460. The quote continues, in relation to the WTO: "The liberalization of international trade over the past fifty years has bought enormous economic benefits, including to developing countries. Would these same benefits have occurred under an international regime of stakeholder governance that would inevitably tend to focus on slicing up the economic pie rather than expand it."

${ }^{120}$ See D. WINICKOFF et. al., pp. 121-122. In this context, the precautionary principle would play a great role in arbitrating justified and unjustified food safety standards and regulations. A thorough study of this principle is however beyond the scope of this paper.

${ }^{121}$ See the very interesting study by Marsha Echols, which analyzes food as a cultural good, triggering culturally-rooted behaviors, which the SPS Agreement tends to disregards by short-sightedly treating food products as objects the regulation of which can be made scientifically. M. A. ECHOLS, Food
} 
In discharging their monitoring function, public authorities should take account of the transnational character of standard setting, and be mindful of the trade-distorting effects fragmented national policies can have. It would thus be advisable that they would coordinate their monitoring of private food safety standards at the transnational level, independently from the WTO, so as not to repeat the shortcomings of the WTO-Codex linkage. They should however seek a structural (but not hierarchical) cooperation with the WTO to ensure that the food safety agenda does not run counter to the free trade agenda. The monitoring of private food standards could take place a priori, but also a posteriori, with some kind of judicial review mechanism. ${ }^{122}$ This judicial review mission should however not be placed in the hands of the WTO Dispute Settlement Body, as we have already underlined its free trade bias.

This de-coupling of the food safety and free trade agendas may seem to weaken the WTO by confiscating one of its most powerful tools: the disciplining of food safety standards as trade barriers. However, we have reason to think that it would in fact strengthen the WTO, as the latter could no longer be accused of adulterating public interests values, such as food safety, for the profit of free trade objectives, which mainly benefit large business entities. This re-balancing would represent a gain in legitimacy for the WTO, which could possibly also result in buttressing its civil society support, and, consequently, its effectiveness. ${ }^{123}$

Safety and the WTO - The Interplay of Culture, Science and Technology, London/The Hague/New York, Kluwer Law International, 2001, 180 p.

${ }^{122}$ See M. A. LIVERMORE, op. cit., pp. 795-796.

${ }^{123}$ See G. R. SHELL, "The Trade Stakeholders Model and the Participation of Private Parties in the World Trade Organization”, 17 U. Pa. J. Int'l Econ. L. 359, 1996, pp. 370 ff. 


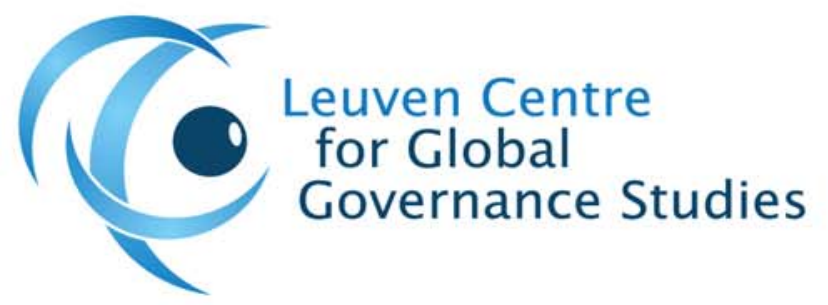

The Leuven Centre for Global Governance Studies is an interdisciplinary research centre of the Humanities and Social Sciences at the Katholieke Universiteit Leuven. It was set up in the Spring of 2007 to promote, support and carry out high-quality international, innovative and interdisciplinary research on global governance. In addition to its fundamental research activities the Centre carries out independent applied research and offers innovative policy advice and solutions to policy-makers on multilateral governance and global public policy issues.

The Centre brings together talent from throughout the University. It operates on the basis of co-ownership and the strong conviction that interdisciplinary research creates added value to resolve complex multi-faceted international problems. The Centre promotes pioneering projects in law, economics and political science and actively initiates and encourages interdisciplinary, cross-cutting research initiatives in pursuit of solutions to real world problems. The cross-cutting initiatives are thematic projects around which University researchers join forces across disciplines to forge responses to complex global challenges. The cross-cutting initiatives address critical issues in relation to globalization, governance processes and multilateralism, with a particular focus on the following areas: (i) the European Union and global multilateral governance; (ii) trade and sustainable development; (iii) peace and security, including conflict prevention, crisis management and peacebuilding; (iv) human rights, democracy and rule of law.

In full recognition of the complex issues involved, the Centre approaches global governance from a multilevel and multi-actor perspective. The multi-level governance perspective takes the interactions between the various levels of governance (international, European, national, subnational, local) into account, with a particular emphasis on the multifaceted interactions between the United Nations System, the World Trade Organization, the European Union and other regional organizations/actors in global multilateral governance. The multi-actors perspective pertains to the roles and interactions of various actors at different governance levels, these include public authorities, non-governmental organizations and private actors such as corporations.

For more information, please visit the website www.globalgovernancestudies.eu

Leuven Centre for Global Governance Studies

Europahuis, Blijde Inkomststraat 5, 3000 Leuven, Belgium

Tel. ++32 $16328725 \quad$ Fax ++32 16328726

info@ggs.kuleuven.be

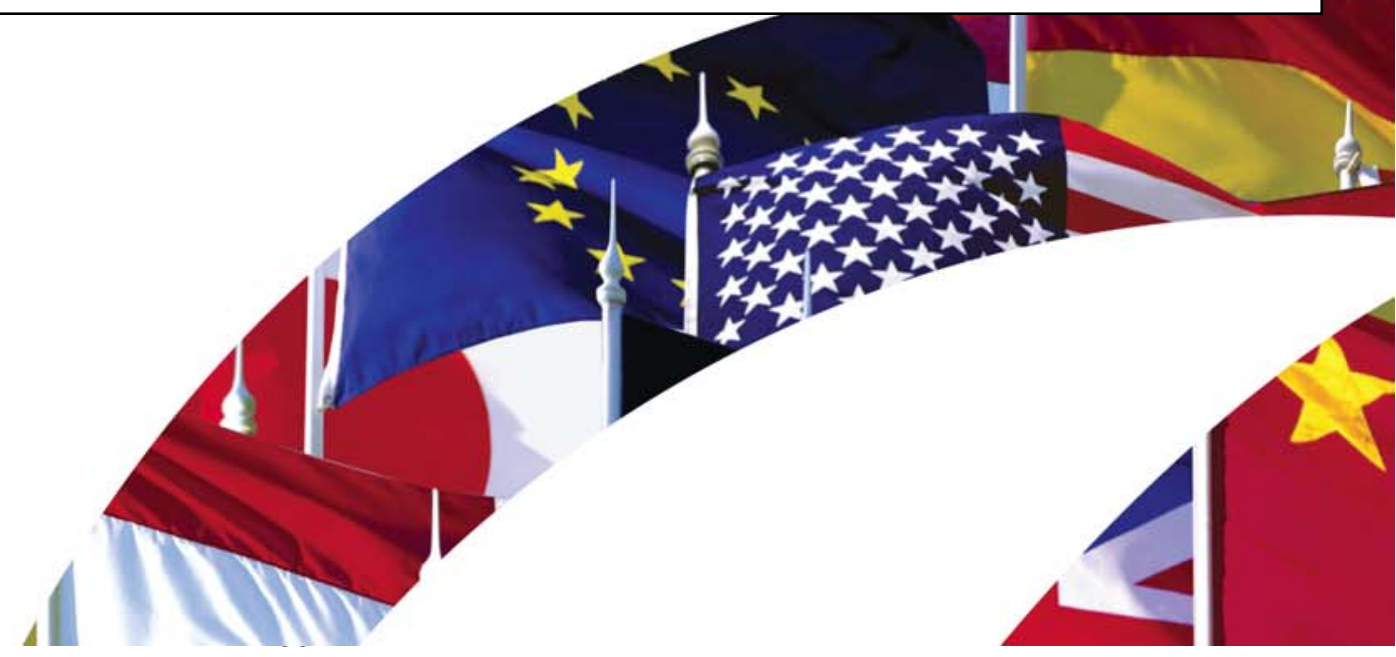

